\title{
ILMU SOSIAL, BUDAYA INTELEKTUAL DAN SEMANGAT KENABIAN: TELAAH PENGEMBANGAN ILMU SOSIAL NUSANTARA
}

\author{
Syarifuddin Jurdi \\ Unversitas Islam Negeri (UIN) Alauddin Makassar \\ Email: syariffudin@gmail.com
}

\begin{abstract}
Abstrak
Indonesia atau dalam bahasa kultural disebut dengan istilah nusantara merupakan wilayah terbentang dari Sabang sampai Merauke, meliputi berbagai pulau, adat-istiadat, bahasa, agama, kebudayaan dan tradisi-tradisi sosial yang sangat beragam. Tulisan ini akanmembentangkan kondisi obyektif perkembangan ilmu sosial nusantara serta kemungkinan pengembangan ilmu sosial yang khas Indonesia, ilmu sosial yang dikonseptualisasi dari tradisi sosial budaya masyarakat Indonesia sendiri. Upaya konseptualisasi ilmu sosial ini harus bersinergi antara spirit pengembangan ilmu para ilmuwannya dan dukungan Negara pada sisi lain, tentu saja pengembangan ilmu sosial di masa depan dengan politik pemihakan Negara yang disertai dengan memasukkan nilai-nilai kebudayaan sebagai materi perkuliahan.Dengan mengurai kesejarahan sosial, artikel ini menyuguhkan bahasan tentang historisitas Ilmu Sosial, Pembentukan Blok Intelektual, Pelembagaan Ilmu Sosial di nusantara serta refleksinya, dan spirit profetik dan asketisme intelektual.
\end{abstract}

Kata Kunci: ilmu sosial, budaya intelektual, spirit profetik

\begin{abstract}
Indonesiaorin theculturallanguageis called by thenusantara is a regionstretching fromSabang toMerauke, includes variousislands, customs, language, religion, cultureandsocial traditions. Thisarticleattempts to laythe objective conditions ofthe development ofsocial sciencesof the nusantara and the possibledevelopment ofa typicalIndonesiansocial sciences. The socialscienceshere areconceptualizedfrom thesocial and culturaltraditions ofIndonesiaitself. Conceptualisationof social scienceshould besynergic betweenthe spirit ofthe development ofthe science ofits scientistsand supportcountriesonthe other hand, of coursethe development ofsocial sciencesin the future bypoliticalpartialityof stateaccompaniedby incorporatingcultural valuesaslecture material. Withsocialhistoricalparse, this article presents adiscussionaboutthe historicityof social sciences, forming the intellectual block,institutionalization ofsocial sciencesinthe nusantara andits reflection, and thepropheticspiritandintellectualasceticism.
\end{abstract}

Keywords: social sciences, intellectuality culture, prophetic spirit

\section{Latar Belakang}

Indonesia atau dalam bahasa kultural disebut dengan istilah nusantara merupakan wilayah terbentang dari Sabang sampai Merauke, meliputi berbagai pulau, adat-istiadat, bahasa, agama, kebudayaan dan tradisi-tradisi sosial yang sangat beragam, membentuk Indonesia yang memiliki kekayaan budaya yang sangat menakjubkan. Kekayaan budaya bangsa tersebut memunculkan 
optimisme dapat mengembangkan ilmu sosial yang mencerminkan kondisi obyektif masyarakat nusantara. Proses penggalian nilai-nilai budaya dalam khasanah akademik sudah dilakukan sejak abad ke-19, dimulai oleh sarjana asing, kemudian berkembang menjadi studi yang diminati oleh sarjana Indonesia sendiri.

Budaya, agama dan adat-istiadat secara ideal mestinya menjadi sumber teori-teori sosial yang perlu dikaji dan menjadi sumber diskusi di berbagai kampus sesuai dengan karakter lokal dimana kampus tersebut eksis. Misalnya, kampus-kampus yang tersebar di Jawa menjadikan kebudayaan Jawa sebagai sumber utama teoritisasi ilmu sosial, kampus-kampus di Sulawesi menjadikan kebudayaan Bugis-Makassar sebagai sumber teori sosial, kampus-kampus di Sumatera bisa menjadikan budaya Minang, Melayu, Aceh sebagai sumber teori sosialnya. Disinilah problem dunia akademik kita, masih sangat terbatas kampus-kampus yang memasukkan dimensi lokal ini dalam kurikulum sebagai bagian dari politik akademiknya. ${ }^{1}$

Tulisan ini akan memahami kondisi obyektif perkembangan ilmu sosial nusantara serta kemungkinan pengembangan ilmu sosial yang khas Indonesia, ilmu sosial yang dikonseptualisasi dari tradisi sosial budaya masyarakat Indonesia sendiri. Upaya konseptualisasi ilmu sosial ini harus bersinergi antara spirit pengembangan ilmu para ilmuwannya dan dukungan Negara pada sisi lain, tentu saja pengembangan ilmu sosial di masa depan dengan politik pemihakan Negara yang disertai dengan memasukkan nilai-nilai kebudayaan sebagai materi perkuliahan.

\section{Historisitas Ilmu Sosial Indonesia}

Sejak abad ke-19, kajian mengenai masyarakat Nusantara telah dilakukan oleh sejumlah sarjana asing untuk menjelaskan kondisi sosial, budaya, tradisi dan agama masyarakat Nusantara seperti ditemukan karya Thomas Stamford Raffles yang berjudul History of Java, karya ini menggunakan data-data tentang masyarakat nusantara (Jawa) secara lebih baik. Berdasarkan karya tersebut perhatian dan minat untuk mengkaji masyarakat nusantara tumbuh subur di kalangan ilmuwan asing, karena besarnya minat dan perhatian terhadap tradisi sosial budaya masyarakat nusantara tersebut, maka pada awal abad ke-20 dimulai proses pelembagaan ilmu sosial nusantara.

\footnotetext{
${ }^{1}$ Untuk menyebut kampus yang sudah menjadi visi-misi ilmu sosialnya, misalnya Universitas Trunojoyo Madura, Jurusan/Prodi Sosiologi mengembangkan Sosiologi Madura, di beberapa kampus Perguruan Tinggi Islam (UIN, IAIN) sudah memasukkan muatan pengembangan keilmuan yang berfokus pada pengembangan sosiologi Islam, sosiologi profetik, demikian pula dengan antropologi dan ilmu politik.
} 
Dari kerja-kerja intelektual para ilmuwan dengan tujuan pengembangan ilmu, ilmu sosial bergeser menjadi ilmu kekuasaan. Dalam proses pelembagaan Ilmu Sosial Nusantara misalnya, peran negara pada zaman kolonial sangatlah signifikan dengan target politik yakni untuk memahami keadaan sosial ekonomi masyarakat wilayah jajahannya. Berdasarkan sejumlah dokumen sejarah, diperoleh keterangan bahwa Ilmu Sosial Nusantara telah ada sejak abad ke-19, karena itu, ilmu sosial bukanlah yang baru lahir pada abad ke-20 atau setelah Indonesia merdeka, karena telah lama berdiri yang ditandai dengan berdirinya sejumlah lembaga yang bertugas melakukan penelitian terhadap kehidupan sosial dan kebudayaan masyarakat Indonesia yang dilakukan pemerintah kolonial Belanda. Pada 1851 didirikan Royal Institute of Linguistics, Geography and Ethnology of the Netherlands Indie (Koninklijk Instituut Vor Taal-, Land En Volkenkunde Van Nederlandsch-Indie/KITLV) yang bertempat di Leiden. Lembaga ini merupakan lembaga yang paling berjasa dalam membangun pengetahuan tentang penduduk, kebudayaan dan masyarakat Indonesia melalui cabang ilmu Indologie. Kendatipun demikian, pelembagaan ilmu sosial pada masa itu berorientasi pada otoritas politik yang bertujuan untuk membantu pemerintah kolonial merumuskan kebijakan yang dipandang tepat bagi masyarakat Indonesia.

Pada abad ke-19, pemerintah kolonial melakukan berbagai langkah yang dipandang penting bagi proses ekplorasi intelektual dalam rangka membantu pemerintah, tujuan utama dalam memahami masyarakat itu adalah untuk tujuan politik, ekonomi dan kebijakannya. Selama periode yang panjang sejak ilmu-ilmu sosial diperkenalkan di kalangan intelektual kolonial dan elite pribumi tersebut, ilmu sosial telah menjadi alat kepentingan pemerintah, ilmu ini tidak menjadi instrumen untuk mentransformasi masyarakat, apalagi untuk pengembangan ilmu pengetahuan itu sendiri.

Menjelang Indonesia merdeka, ilmu-ilmu sosial mengalami proses kemajuan yang ditandai dengan munculnya sejumlah intelektual Nusantara dari berbagai latar belakang dan mewarnai diskursus tentang kehidupan sosial, kebudayaan, politik dan kepemimpinan. Di kalangan Islam, muncul Tan Malaka dengan sejumlah gagasannya tentang sosialisme-marxisme, Tan Malaka menjadi intelektual Indonesia yang sangat kritis terhadap struktur sosial dan sistem politik yang dipandang tidak membuka ruang bagi rakyat pribumi. Pengaruh pemikiran Karl Marx terhadap Tan Malaka sangatlah kuat, dalam karyanya Madilog (Materialisme, Dialektika dan Logika) misalnya, apa yang ditulis Tan Malaka sangat menonjol pengaruh Marx, itulah yang 
membedakan Tan Malaka dengan intelektual Islam lainnya. Madilog menjadi karya penting yang "memprovokasi” sejumlah aktivis-aktivis sosial keagamaan pada masa itu bahkan hingga kini gagasan Tan Malaka tersebut masih menginspirasi sejumlah kaum muda, karena begitu kuatnya pengaruh Tan Malaka dalam struktur kepemimpinan Sarekat Islam, sehingga partai ini mengalami perpecahan, ada yang disebut dengan SI putih dan SI merah.

Mengenai SI putih dan SI merah tidak akan dijelaskan disini, karena dua kubu itu memiliki strategi yang berbeda dengan tujuan akhir yang sama, Tan Malaka, Kyai Misbach dan kawan-kawannya mendukung ideologi sosialisme-komunisme sebagai ideologi gerakan Sarekat Islam, sementara Tjokroaminoto, Agus Salim dan kawan-kawannya tetap menjadikan Islam sebagai ideologi gerakan Sarekat Islam. Sasarannya adalah rezim yang terus-menerus menindas dan memonopoli segala arena kehidupan sosial politik dan bahkan keagamaan, rezim yang eksploitatif, hegemonik dan penjajahan yang bertentangan dengan nilai-nilai dasar kemanusiaan, kedua kubu Sarekat Islam mengkritik pemerintah dengan cara yang berbeda, tetapi tujuan akhirnya yakni tercapainya suatu tatanan kehidupan yang bebas, merdeka dan berdaulat.

Perbedaan inilah yang mendorong Tjokroaminoto dan Agus Salim menggagas tentang apa yang disebut dengan sosialisme Islam sebagai anti-thesa dari gagasan sosialisme-marxisme Tan Malaka. Dalam Islam menurut pandangan Tjokroaminoto dan Agus Salim terdapat sejumlah doktrin Islam yang mengajarkan bagaimana seharusnya bersikap terhadap kelompok marginal secara ekonomi. Gagasan itu sebenarnya merupakan rangkaian dari apa yang telah dilakukan oleh KHA. Dahlan, pendiri Muhammadiyah yang mengajarkan tentang teologi Al-Ma'un sebagai suatu konsep Islam yang menegaskan pentingnya kepedulian pada kaum dhu'afa, mustad'afin atau wong cilik.

Transformasi ilmu sosial dilakukan secara intensif setelah berdirinya perguruan tinggi di Indonesia, sejak dekade 1930-an ilmu-ilmu sosial termasuk sosiologi telah diajarkan pada sekolah tinggi yang berdiri kala itu, meski belum menjadi suatu disiplin ilmu tersendiri, tetapi matakuliah sosiologi telah diperkenalkan. Pasca decade 1930-an hingga 1940-an, ilmu-ilmu sosial terus dikembangkan sampai kemudian berdirinya sejumlah kampus-kampus besar seperti UGM dan UI yang kemudian membuka program studi/jurusan ilmu-ilmu sosial seperti Sosiologi, Sejarah, Antropologi, Hukum dan Ekonomi.

Pada periode yang hampir bersamaan dengan berdirinya sejumlah perguruan tinggi besar tersebut, peningkatan jumlah akademisi yang menyelesaikan pendidikan tinggi juga sangat 
signifikan. Sejumlah akademisi Indonesia yang telah menyelesaikan pendidikan tinggi setingkat magister dan doktoral seperti beberapa nama sosiolog generasi awal; misalnya Selo Soemardjan yang memperoleh gelar Ph.D dari Cornell University, Harsja Bahtiar yang menyelesaikan MA dari Cornell University dan Ph.D dari Harvard University, Mely G. Tan mendapat gelar MA dari Cornell University dan Ph.D dari Cornell University dan Soelaeman Soemardi yang memperoleh gelar MA dari Cornell University. Pada bidang ekonomi ada Sumitro Djoyohadikusumo, di bidang politik Deliar Noer, antropologi terdapat nama Koentjaraningrat dan bidang-bidang ilmu sosial lainnya.

Pasca para sosiolog lulusan AS tersebut kembali ke Nusantara, ilmu sosial kemudian berkembang berdasarkan perkembangan ilmu sosial di AS, ini kemudian mengganti ilmu sosial kolonial Belanda, para ilmuwan sosial Belanda dan lulusan Belanda seperti Sunario Kolopaking yang merupakan ilmuwan yang pertama mengajarkan sosiologi dalam Bahasa Indonesia dan berlatar belakang Ilmu Hukum di Akademi Ilmu Politik Yogyakarta yang kemudian bergabung ke UGM. Pergeseran itu kemudian semakin menonjol setelah sejumlah sarjana Indonesia kembali dari pendidikan pascasarjananya di AS, khususnya kelompok intelektual beraliran fungsionalisme struktural yang mengutamakan harmoni, kohesi dan integrasi, lebih spesifik yakni kuatnya pengaruh sosiolog AS yang paling terkenal pada masa itu Talcott Parsons yang merupakan tokoh fungsionalisme struktural, maka teori Parsons ini memiliki pengaruh signifikan dalam proses pembangunan nasional.

Dengan pendekatan struktural fungsional model Talcott Parson, bahwa rezim berkuasa menempatkan peranan, norma, nilai dan keabsahan pada pusat analisa sosial dan politik. Dimensi budaya dalam analisa sosial dan politik menjelaskan bahwa terciptanya suatu tata politik yang melintasi kelas sosial, itulah yang kemudian terwujud pada sebagian praktek politik di komunitas kultural tertentu.

Transformasi ilmu sosial mengalami pertumbuhan bersinergi dengan pertumbuhan jumlah intelektual lulusan asing, mereka mengembangkan ilmu sosial yang diintegrasikan dengan nilai-nilai profetik. Pada dekade 1970-an, sejumlah intelektual muda seperti Nurcholis Madjid, Dawam Rahardjo, Abdurrahman Wahid, Ahmad Wahib, Amien Rais, AM. Saefuddin, Kuntowijoyo, Syafii Maarif dan lain sebagainya mulai mengembangkan ilmu sosial alternatif. Dawam Rahardjo misalnya dengan LP3ES-nya mengembangkan ilmu Sosial Nusantara, 
munculnya Jurnal Prisma dan penerbitan karya-karya intelektual Nusantara oleh penerbit LP3ES menjadi bukti akan pentingnya mengembangkan Ilmu Sosial Nusantara.

Selain LP3ES yang merupakan lembaga yang bergerak pada bidang riset dan penerbitan, juga muncul lembaga yang hampir sama didirikan oleh Dawam Rahardjo yaitu Lembaga Studi Agama dan Filsafat (LSAF), melalui LSAF tersebut, Dawam Rahardjo menerbitkan Jurnal Ulumul Qur'an, merupakan jurnal yang sangat berpengaruh pada dekade 1990-an, tulisan-tulisan yang dimuat jurnal Ulumul Qur'an mencerminkan namanya yakni artikel-artikel yang berkaitan dengan ilmu, Islam, peradaban, kemanusiaan, politik, tasawuf dan lain sebagainya. Inilah yang saya anggap sebagai jurnal yang berkontribusi bagi upaya untuk melahirkan diskursus alternatif Ilmu Sosial Nusantara dengan mengintegrasikan dengan nilai profetik.

Pengembangan ilmu sosial dapat mengikuti apa yang telah dihasilkan oleh sarjana asing yang menulis Indonesia, misalnya antropolog Clifford Geertz mengenai budaya kekuasaan Jawa yang tentu berpengaruh signifikan bagi perkembangan ilmu politik Indonesia, Benedic RO'G Anderson menawarkan teori mengenai kekuasaan Jawa dan "komunitas bayangan", Herbert Feith dan Lance Castle mengenai teori politik aliran, William Lidle, Mitsuo Nakamura, J.H. Booke (teori dual society), Robert Hefner, Harold Crouch, Herry J. Benda, Wertheim, BJ. Boland dan sejumlah sarjana asing lainnya. Hasil karya mereka dapat menjadi eksemplar mengembangkan sosiologi, antropologi dan ilmu politik Indonesia.

Secara obyektif harus diakui bahwa para sarjana asing yang melakukan penelitian mengenai kehidupan sosial, politik, budaya dan agama masyarakat Indonesia sejak lama sangat mendominasi wacana Ilmu Sosial Nusantara, bahkan apa yang mereka hasilkan dari penelitiannya menjadi bacaan dan bahan diskusi di berbagai kampus di Indonesia. Bantuan asing atas biaya riset dan berbagai kebutuhan akademis lainnya dalam meneorisasi masyarakat Nusantara merupakan bagian tersendiri yang dihadapi oleh ilmuwan sosial.

\section{Pembentukan Blok Intelektual}

Gerakan pribuminisasi ilmu sosial menghadapi masalah dalam dirinya sendiri, artinya para ilmuwan yang seharusnya mengembangkan ilmu sosial justru terjebak dalam jejaring kekuasaan, disiplin Indologi yang dikembangkan pemerintah kolonial dengan berusaha mempelajari geografi, kebudayaan, bahasa, dan masyarakat Indonesia sebagai bagian dari rencana penguasa untuk menyusun sistem sosial baru. Studi mengenai masyarakat dan 
kebudayaan Nusantara merupakan studi yang bertujuan untuk mengukuhkan dominasi kekuasaan pemerintah, ilmuwan sosial umumnya menjadi intelektual yang mengabdi pada kekuasaan, kendatipun tersedia berbagai peluang untuk mengembangkan Ilmu Sosial Nusantara melalui berbagai riset yang mereka lakukan.

Para ilmuwan sosial semakin intensif berinteraksi dengan pusat kekuasaan, khususnya pasca Indonesia merdeka. Ketika kebijakan pembangunan nasional menjadi mandat politik pemerintah untuk mentransformasi ekonomi masyarakat di dalam negara. Dalam konteks inilah keterlibatan para sarjana sosial dalam urusan kekuasaan menjadi sangat penting, tidak hanya memastikan kebijakan pemerintah mencapai target yang diinginkan, tetapi juga sebagai arena memperkuat dominais Negara terhadap kehidupan sosial masyarakat. Memahami karakter politik yang dikembangkan rezim berkuasa, maka dapat diperkirakan bahwa kebijakan-kebijakan pemerintah dalam mentransformasi masyarakatnya memerlukan keterlibatan ilmuwan sosial untuk menjelaskan dan mengemukakan masalah tertentu yang berkaitan dengan kondisi sosial, ekonomi, budaya, dan politik yang bisa mendukung ataupun menghambat proses transformasi masyarakat menuju kepada kehidupan yang lebih maju dan beradab.

Konteks historis kemunculan ilmu sosial Indonesia dapat dimaknai sebagai suatu gerakan yang memperoleh legitimasi cultural dari para intelektual Indonesia yang merasa terpanggil untuk mentransformasi gagasan sosialnya mengenai Indonesia dan kerangka kerja masa depan. Dalam perkembangannya, spirit pribuminisasi tidak pernah berhenti disuarakan oleh intelektual Indonesia yang bermuara pada pembentukan blok tersendiri bagi pengembangan ilmu sosial Indonesia. Setidaknya terdapat tiga blok besar yang terbangun dalam sejarah ilmu sosial Nusantara;

Pertama, blok yang terbentuk pada pra kemerdekaan yang ditandai dengan pertumbuhan ilmu sosial yang prakarsai oleh Tjokroaminoto (sosialisme Islam); Tan Malaka (Madilognya); Ahmad Dahlan (teologi Al-Ma'un- mengusung kolektivisme); Soekarno dan Hatta (nasionalisme); Sutan Syahrir (sosialis) serta lapisan intelektual generasi awal pembentukan ilmu sosial Nusantara. Pembentukan blok gerakan ini sebagai manifestasi dari panggilan untuk meletakkan dasar bagi gerakan ilmu yang relevan dengan keindonesiaan, ilmu sosial yang bahan dasarnya berasal dari kondisi aktual masyarakat Indonesia, sekaligus sebagai peta jalan mengenai arah pengembangan ilmu sosial Indonesia yang lebih spesifik, ilmu sosial yang dikembangkan dari kultur sosial-budaya masyarakat Indonesia. 
Kedua, blok yang terbentuk pasca kemerdekaan dengan terbentuknya sejumlah univeristas atau perguruan tinggi dengan tujuan untuk menciptakan lapisan intelektual terdidik. Generasi lapis ini terdiri dari para intelektual terpelajar lulusan perguruan terkemuka luar negeri seperti Selo Soemardjan; Harsja Bahtiar; Mely G. Tan;Soelaeman Soemardi; Sumitro Djoyohadikusumo (ekonom terkemuka); Deliar Noer (Doktor ilmu politik pertama lulusan Amerika); Koentjaraningrat (antropolog terkemuka lulusan Amerika) dan bidang-bidang ilmu sosial lainnya.Meningkatnya lulusan luar negeri (AS) menyebabkan ilmu sosial menjadi ilmu yang sangat pragmatis, orientasinya pada pemecahan masalah sosial dengan sumber teori-teori sosial yang sudah tersedia dalam literature Barat, dengan kata lain, terjadi proses transmisi ilmu sosial Barat melalui sarjana Indonesia secara massif, menyebabkan melemahnya etos merumuskan ilmu sosial Nusantara sebagaimana yang telah dimulai oleh ilmuwan pra kemerdekaan.

Ketiga, blok baru ilmuwan sosial yang muncul pada decade 1970-an, ditandai munculnya penerbitan jurnal Prisma dan berkembangnya penerbitan karya-karya intelektual Indonesia. Para aktor pada blok ini direpresentasi oleh sejumlah ilmuwan dari berbagai wilayah dan kampus, di Jakarta terdapat sejumlah nama diantaranya Taufik Abdullah, Nurcholish Madjid, Ignas Kleden, Dawam Rahardjo, di wilayah Yogyakarta-Jawa Tengah terdapat Kuntowijoyo, Syafii Maarif, Amien Rais, Arief Budiman, wilayah Jawa Timur terdapat Abdurrahman Wahid, Fuad Amsyari dlll., wilayah Makassar terdapat Mattulada dan sebagainya. Blok baru ini hadir bersamaan dengan makin kuatnya cengkraman rezim Orde Baru terhadap sejumlah arena kehidupan masyarakat, sehingga ruang-ruang diskursus akademik berada dalam wilayah kontrol dan kendali Negara.

Pertumbuhan ilmuwan sosial dalam beberapa tahun terakhir yang makin meningkat tidak berkorelasi dengan menguatnya studi dan kajian mengenai keilmuan sosial humaniora yang menasional, studi yang mengangkat topik-topik kenusantaraan, bahkan Heru Nugroho (2012) menyebutnya dengan istilah, intelektual tukang, intelektual bazaar atau juga disebut intelektual pamer (intellectual of the spectacle). Rendahnya semangat asketisme ini menyebabkan sulitnya melakukan transformasi nilai-nilai budaya bangsa dalam proses pendidikan. Dunia pendidikan tidak lagi menjadi arena yang "steril" dari kepentingan kapital, tetapi justru banyak kalangan mendirikan kampus dan sekolah bukan untuk kepentingan pengembangan ilmu pengetahuan, melainkan proses akumulasi kapital para pendirinya. 
Pada sisi lain muncul aktor-aktor pergerakan yang melakukan proses emansipasi dan transformasi masyarakat agar terbebas dari buta aksara yakni muncul program Indonesia mengajar yang diprakarsai Anies Baswedan sebagai bagian dari aktualisasi misi profetik untuk membebaskan manusia dari belenggu kebodohan, keterbelakangan dan kemiskinan. Masyarakat yang hidup dalam tiga keadaan ini akan mudah dimobilisasi, dimanipulasi dan dipolitisasi oleh elite politik dan para pemilik modal yang memiliki agenda tertentu.

\section{Pelembagaan Ilmu Sosial Nusantara}

Sejalan dengan proses pembentukan blok intelektual yang hingga kini belum banyak mengalami kemajuan, seperti inisiasi Dawam Rahardjo mendirikan Komunitas Epistemik Muslim Indonesia (KEMI), ternyata kurang diminati. Pembentukan blok intelektual tersebut sebagai bagian dari gerakan yang mengompromikan identitas nasional dengan kecendrungan umum pengembangan ilmu sosial di Barat, tanpa mengisolasi diri dengan ilmu sosial yang berkembang di Barat, melainkan proses pembentukan tradisi-tradisi intelektual yang menegosiasikan tuntutan untuk melahirkan ilmu sosial yang khas Indonesia dengan proses transmisi ilmu sosial dari luar (Syed Farid Alatas, 2006). Dalam konteks keindonesiaan, tulisan Ignas Kleden "Sikap Ilmiah dan Kritik Kebudayaan(1988) memberikan penegasan yang penting mengenai kondisi Ilmu Sosial Indonesia, khususnya upaya melakukan indigenisasi ilmu-ilmu sosial. Indigenisasi (pribuminisasi) sebagai gerakan intelektual untuk membangun tradisi akademik sendiri berdasarkan tradisi social dan tradisi intelektual masyarakat Indonesia. Gerakan pribuminisasi merupakan gerakan yang perlu dilakukan dengan mendorong institusi akademik untuk menerapkan politik akademik yang memihak pada pengembangan ilmu sosial Indonesia dan muncul-berkembangnya sikap asketisme intelektual Indonesia

Kemandegan pembentukan blok intelektual Indonesia disebabkan oleh dua factor yang saling mempengaruhi yakni; pertama, proses transformasi sosial dan dinamika kekuasaan telah membentuk suatu orientasi tersendiri bagi ilmu-ilmu sosial, tidak hanya berkaitan dengan pentingnya pusat kekuasaan memahami persoalan empirik yang dihadapi oleh masyarakat yang dipimpinnya, tetapi juga untuk merekonstruksi tata kehidupan sosial yang mencerminkan realitas

yang hidup dalam masyarakat. Kedua, rendahnya sikap asketisme ilmuwan sosial Indonesia untuk mengembangkan ilmu yang bersesuaian dengan karakter dasar masyarakat. Antara 
kuatnya kepentingan otoritas politik dengan rendahnya semangat ilmuwan sosial, akan mengikis - bahkan menumpulkan optimisme membangun tradisi ilmu sosial sendiri.

Tradisi awal dalam disiplin ilmu sosial kemanusiaan dapat menjadi dasar untuk mengembangkan ilmu sosial Indonesia dan membentuk blok baru yang otonom dari pengaruh Barat. Tradisi keilmuan yang sudah diletakkan oleh sarjana asing yang melakukan studi terhadap kehidupan sosial budaya masyarakat Indonesia tidak diteruskan oleh sarjana Indonesia menjadi suatu tradisi akademik yang kuat. Pembentukan institusi pendidikan pada awal kemerdekaan tidak diorientasikan untuk kepentingan ilmu, melainkan berorientasi kekuasaan, jadi berkembanglah ilmu sosial yang pro penguasa, berikut para ilmuwannya mengabdi untuk kepentingan kekuasaan. Pada tahun 1924 berdiri Sekolah Tinggi Hukum yang membuka ruang pengajaran ilmu social, kemudian Akademi Ilmu Politik di Yogyakarta tahun 1948, Universitas Nasional (Unas) di Jakarta tahun 1949 yang diikuti dengan pendirian perguruan tinggi lainnya. Proses pelembagaan ini bertujuan untuk mencetak kaum terpelajar yang professional membantu pemerintah, itulah yang menjadi ciri dari Negara berkembang.

Kaum terpelajar yang "tergoda" dengan kekuasaan akan sulit hadir sebagai jejaring pengembangan ilmu sosial, bahkan para pengajar dalam bidang ilmu sosial (sejarah, sosiologi, antropologi) masih sulit meninggalkan tradisi yang membesarkan ilmu sosial yakni Eropa dan Amerika, tokoh-tokoh klasik dalam bidang sosiologi misalnya selalu dirujuk menjadi bahan diskusi di perkuliahan sosiologi-antropologi, kendatipun apa yang dirujuk dari teoritisi Eropa dan Amerika itu sebagai sesuatu yang tidak perlu dipersoalkan, hanya saja perlu dikonfirmasi dan didialogkan dengan fenomena sosial masyarakat Nusantara. Forum perkuliahan ilmu sosial harus menunjukkan kekhasan yang sesuai dengan konteks mengapa ilmu sosial perlu dipelajari pada wilayah tertentu di Nusantara. Misalnya ilmu sosial dibuka di perguruan tinggi di Jawa, maka perlu memberikan pelajaran yang secara spesifik mengenai masyarakat Jawa, demikian pula dengan pembukaan disiplin sosial di Sulawesi, harus merefleksikan kebudayaan dan struktur sosial masyarakat Bugis, Makassar dan lainnya, demikian pula di Sumatera harus ada yang lebih khas yang berbeda dengan wilayah lain. Dengan cara semacam ini, proliferasi pengajaran ilmu sosial akan mendorong pada pribuminisasi dan penguatan simpul-simpul pengajaran ilmu sosial yang akan membantu penemuan tradisi alternatif ilmu sosial Nusantara. 


\section{Refleksi terhadap Tradisi Ilmuwan Sosial Nusantara}

Tugas utama pemerintah adalah mengatasi berbagai gejolak yang muncul di daerahdaerah, istilah nation building sebenarnya merupakan upaya untuk menciptakan integrasi nasional (periode awal kemerdekaan), memperkuat ketahanan pangan, modernisasi sektor pertanian dan berbagai gerakan lainnya (pemerintah Orde Baru), kini rezim mestinya mentransformasi dengan merevitalisasi nilai-nilai budaya lokal sebagai instrumen membangun kemandirian nasional melalui politik pendidikan dan politik akademik yang memihak pada gerakan pribuminisasi ilmu.

Gerakan ilmu dewasa ini harus mengarah pada agenda pembauran kebangsaan dan penguatan identitas akademik yang memihak pada nilai-nilai budaya bangsa untuk memperkuat NKRI. Kontribusi rezim Soekarno dalam penguatan identitas kenusantaraan dapat menjadi titik point untuk mengembangkan ilmu sosial budaya atau ilmu sosial humaniora yang lebih independen. Identitas kenusantaraaan dan integrasi sosial yang diperjuangkan rezim Soekarno menjadi penting bagi pembangunan nasional tanpa mengabaikan kebudayaan nasional.

Kebijakan yang berorientasi pada aspek ekonomi yang pro pasar dan bercorak liberal oleh sebagian ilmuwan sosial sebagai kebijakan yang akan menolong pertumbuhan perekonomian nasional dan mengentaskan kemiskinan. Dengan pembangunan ekonomi yang mantap akan memberi kontribusi bagi partisipasi politik warga yang tinggi dalam proses pembangunan serta menjamin terciptanya kehidupan sosial yang harmonis. Peningkatan pertumbuhan ekonomi akan berkorelasi dengan aspek sosial seperti tersedianya lapangan kerja yang memadai bagi rakyat serta menunjukkan bahwa pemerintah memiliki komitmen dan tanggungjawab sosial yang tinggi terhadap warganya.

Sifat ilmu menjadi penting untuk memasukkan suatu disiplin dalam kategori ilmu sosial, menurut Taufik Abdullah bukan sifat ilmu sosial yang menentukannya, tetapi sistem ilmu pengetahuan yang memiliki hubungan dengan sesuatu di luar dirinya yakni negara dan persoalan-persoalan lain yang terkait, sehingga Abdullah memasukkan ilmu humanistik sebagai bagian dari ilmu sosial. Terdapat fenomena yang tentu penting untuk mempertanyakan orientasi pembangunan ekonomi yakni angka kemiskinan tetap tinggi, bahkan angka kemiskinan absolut yang tidak terjamah oleh pembangunan ekonomi sangat tinggi, selain terdapat pula kategori yang oleh ilmuwan sosial dimasukkan ke dalam kategori kemiskinan relatif, mereka ini merupakan dampak langsung dari pembangunan ekonomi. 
Kritik terhadap ilmuwan sosial sebenarnya sudah lama dilontarkan, misalnya George J. Aditjondro membedakan antara Ilmu Sosial Nusantara dengan pekerjaan ilmuwan sosial Nusantara, Aditjondro mengatakan bahwa; (1). Proses identifikasi antara "ilmu sosial" dan "apa yang ilmuwan sosial lakukan"; (2). Hubungan antara negara dan masyarakat dengan mengimbau agar para ilmuwan sosial kembali pada misinya sebagai "ilmu masyarakat" dan bukannya "ilmu negara"; (3). Supremasi moral ilmu sosial dalam hubungannya dengan ilmu-ilmu alam; (4). Dikotomi idealis antara komunitas-komunitas “ilmiah” dan "politik" (Aditjondro, 1997:41-50).

Untuk memahami kecenderungan ilmuwan sosial Nusantara, Aditjondro menggunakan term yang digunakan Antonio Gramsci tentang intelektual tradisional dan intelektual organik, daripada memilah, mana ilmu sosial dan ilmu ekonomi, dengan menggunakan kategori Gramsci akan mempermudah memahami peran yang dimainkan oleh intelektual tradisional sebagai cendekiawan yang terpisah dari induk akademik mereka, serta ilmuwan sosial organik pada kelas penguasa yang dapat dibagi menjadi antara mereka yang bekerja untuk elite politik dan mereka yang bekerja untuk elite bisnis, juga akan memahami mereka yang organik pada kelas pekerja. Selain term Gramsci, Aditjondro juga menggunakan term Michel Foucault tentang cendekiawan universalisal dan cendekiawan spesifik, menurut Foucault cendekiawan universal ialah model kuno dalam menghubungkan teori dan praktik di kalangan kaum cendekiawan "kiri", yaitu agar diakui bahwa dengan kepastian mereka untuk menguasai kebenaran dan keadilan, berhak berbicara sebagai jurubicara universal.Sementara cendekiawan spesifik adalah mereka yang membiasakan diri bekerja, tidak dalam modalitas dari sektor "universal", "adil-dan-benar-untuksemua", melainkan dalam sektor khusus yaitu pada tempat-tempat yang tepat, dimana kondisi hidup atau pekerjaan yang menempatkan mereka (Ibid.:43).

Ilmuwan jenis yang spesifik melepaskan dirinya dari isu-isu umum (universal), tetapi secara langsung menfokuskan perhatian pada hal-hal spesifik yang terjadi sehingga Foucault membagi jenis cendekiawan spesifik menjadi; 1) mereka menjadikan masalah-masalah perjuangan sehari-hari yang materiil dan nyata; 2) mereka dihadapkan pada lawan yang sama yakni proletariat juga dan korporasi multinasional, aparat pengadilan dan polisi, serta kaum spekulator harta kekayaan (ibid. : 43).Fokus perhatian masalah-masalah spesifik ini menjadikan mereka, pada satu sisi dekat dengan kaum proletariat dan massa, sekaligus juga menjadikan kelompok tersebut sebagai lawan dalam hal-hal tertentu. 
Mensinergikan misi negara untuk menjamin suatu tata sosial yang egaliter dengan mendorong partisipasi warga dalam proses sosial politik serta kekuatan masyarakat yang menopang bekerjanya negara untuk mewujudkan cita-cita sosial menjadi titik sentral secara teoritik yang dikehendaki oleh para ilmuwan sosial. Hubungan yang bersifat simbiosis mutualisme antara negara dan masyarakat menjadi ciri dari negara yang demokratis, negara yang menjamin terealisasinya jejaring sosial yang didasarkan atas kesukarelaan daripada relasi antar warga yang didasarkan pada aturan-aturan yang bersifat kaku dan rigid hasil pembentukan negara. Namun apa yang terjadi pada masa Orde Baru, masyarakat berada dalam posisi yang sangat tidak berdaya, bahkan kekuatan civil society mengalami kemerosotan yang sangat meyakinkan, negara hadir sebagai satu-satunya kekuatan yang menjamin berbagai kebutuhan dan keperluan warganya.

Dalam kultur politik dan kultur sosial seperti itu, ilmuwan sosial kehilangan spiritnya untuk membangun budaya akademik yang independen, budaya akademik yang terbebas dari pengaruh dan kooptasi ilmu sosial dari luar. Implikasi politik dari interaksinya dengan kekuasaan, baik di masa lalu maupun pasca kemerdekaan menyebabkan ilmu sosial menjadi ilmu kekuasaan, dengan baik Abdullah mengatakan bahwa

"Ilmu sosial telah menjadi ilmu negara, dalam arti bahwa, kepadanya diharap agar mengabdi kepada kepentingan negara seperti yang saya ingat, pembagian teoritis antara negara dan masyarakat telah diubah oleh sikap ideologis Orde Baru. "Integralisme" menurut pemikiran konstitusional penguasa telah menjadi sangat dominan, sehingga dipandang sebagai warisan tradisi budaya nasional yang sebenarnya. Implikasi hubungan yang rumit antara kategorisasi realitas secara teoritis dan daya tarik ideologis dengan gagasan bahwa fungsi-fungsi kekuasan negara yang sah atas perkembangan Ilmu Sosial di Indonesia, yang hanya dapat “dibedakan tapi tidak dapat dipisahkan" (Taufik Abdullah, 1997: 57-58).

Kecendrungan baru lainnya yakni hadirnya konsep integrasi keilmuan yang berkembang dalam kultur akademik belakangan ini merupakan manifestasi dari panggilan untuk melakukan gerakan pribuminisasi ilmu sosial dan semangat melakukan emansipasi-transformasi masyarakat menuju masyarakat yang beradab menjadi tugas bersama ilmuwan sosial dengan otoritas politik. Penataan ulang identitas social masyarakat sebagaimana penataan ulang identitas akademik harus bersinergi dengan gerakan mencerahkan dan membebaskan masyarakat dari kooptasi dan hegemoni kelas-kelas berkuasa, yakni mereka yang menguasai sumber daya dalam jumlah yang banyak. 
Politik akademik di berbagai kampus dapat dimulai dengan memasukkan kurikulum yang mencerminkan spirit pengembangan ilmu yang sesuai dengan corak dan karakter sosial budaya masyarakat. Disinilah pentingnya memahami proses integrasi para ilmuwan sosial dengan kekuasaan merupakan suatu keniscayaan dalam pembentukan masyarakat modern, hanya yang patut diperhatikan adalah proses integrasi tersebut sedapat mungkin merefleksikan pluralitas masyarakat, kebutuhan untuk memahami kemajemukan budaya, bahasa dan adat-istiadat masyarakat tidaklah dapat dirumuskan secara spekulatif, perlu dilakukan analisis dan kajian yang komprehensif mengenainya agar dalam konstruksi sistem sosial politik bangsa tidak bersifat eksklusif.

Kehadiran para ilmuwan sosial sangat diperlukan untuk menjelaskan secara sosiologis, antropologis dan geografis suatu masyarakat, penjelasan yang didasarkan pada fakta-fakta sosial masyarakat, bukan suatu penjelasan yang lahir dari parameter-parameter yang telah dirumuskan olehilmuwan sosial Barat. Apabila para ilmuwan sosial terlalu banyak tergantung atau menggantungkan diri dengan penguasa, tentu akan mengurangi bobot pengembangan ilmu. Disinilah apa yang disebut oleh sebagian ilmuwan sosial kritis sebagai suatu proses birokratisasi pengetahuan sosial yang mendorong terjadinya penyebaran pengetahuan yang diorganisir, dibiayai, dan disesuaikan dengan orientasi umum pembangunan nasional yang bertumpu pada aspek ekonomi.

Dengan menggunakan term kontsruktivisme bahwa perubahan sosial dan transformasi masyarakat, dari kehidupan agraris ke kehidupan modern, industri (mesin dan jasa) merupakan kebutuhan melakukan rekonstruksi simpul-simpul kebudayaan yang dikontribusikan dalam kehidupan sosial politik masyarakat. Kebutuhan untuk melakukan rekonstruksi merupakan agenda kolektif bangsa dalam rangka mencipta dan menghasilkan tradisi intelektual yang dilandasi budaya bangsa. Dengan langgam seperti itu, ilmu sosial akan memiliki pertautan antara bangunan teori sosial dengan realitas yang dihadapinya, pertautan antara masalah kajian atau penelitian sosial dengan upaya mengatasi persoalan yang nyata hadir di masyarakat. Ilmu Sosial Nusantara bukanlah disiplin yang tanpa kepentingan, kendati harus tetap selalu otonom dan independen, tetapi juga kenyataannya mereka harus hadir dalam setiap arena kehidupan kolektif bangsa untuk mengukuhkan identitas nasional yang nyaris hilang dalam percaturan politik global. 
Dekonstruksi, rekonstruksi, konstruksi atau istilah lain dapat dipergunakan untuk mentransformasi Ilmu Sosial Nusantara dengan mengangkat nilai-nilai kebudayaan sebagai instrumen utamanya serta menjadikan isu-isu sosial kemanusiaan Nusantara sebagai obyeknya. Inilah yang barangkali dilakukan oleh ilmuwan sosial pada dekade 1980-andengan melakukan gerakan dekolonisasi ilmu sosial seperti yang dilakukan Ignas Kleden (Sikap Ilmiah dan Kritik Kebuadayaan, 1987); Iwan Gardon Sudjatmiko (Indigenisasi Sosiologi Indonesia, Jurnal Masyarakat, Vol. No. 6/1998: 25-44); Kuntowijoyo, (Paradigma Islam: Interpretasi Untuk Aksi, 1991; Islam Sebagai Ilmu, 2004; Muslim Tanpa Masjid, 2001); Dawam Rahardjo (Ensiklopedi Al-Qur'an: Tafsir Sosial Berdasarkan Konsep-konsep Kunci, 2001; Paradigma Al-Qur'an, 2005); Sartono Kartodirdjo (Pemikiran dan Perkembangan Historiografi Indonesia: Suatu Alternatif, 1982); Taufik Abdullah (Ilmu Sosial dan Peranannya di Nusantara dalam Prisma, 1983) dan berbagai karya intelektual lainnya. Tujuan utamanya adalah membangun tradisi Ilmu Sosial Nusantara yang otonom dengan mempertanyakan kembali pentingnya dan relevansi masalah-masalah yang ditanganinya. Para ilmuwan sosial langsung berhadapan dengan nilainilai, norma-norma dan kebudayaan pokok bangsanya. Komitmen ilmuwan sosial pada dasarnya merupakan komitmen untuk menciptakan kehidupan adil dan makmur (Soedjatmoko, 1995: 115116).

Dekonstruksi sebagai jalan masuk untuk melakukan kerja-kerja intelektual dalam rangka "membasmi" kemalasan dan keterbelengguan akademik. Dalam konteks ini, dekonstruksi bermaksud mentransformasi nilai-nilai budaya dalam proses pendidikan secara sistematis, terencana dan terlembaga. Kebudayaan bangsa menjadi faktor integratif dalam proses pembangunan dunia pendidikan yang independen, terbebas dari pengaruh ilmu pengetahuan dari luar masyarakat nusantara.

Etos para ilmuwan akan sangat ditentukan oleh sistem dan struktur sosial masyarakat yang secara umum dapat dikatakan sebagai hasil perkawinan antara feodalisme dan kolonialisme telah melahirkan sikap umum warga yakni sikap patron-client yang tentu berpengaruh pula bagi tumbuhnya kepercayaan diri para ilmuwannya ketika berhadapan dengan teori-teori sosial yang dirumuskan sarjana asing, bahkan kritik terhadap sikap "membabi buta" dalam meniru dan mengadopsi metode-metode dan teori-teori yang dihasilkan sarjana Barat menjadi masalah tersendiri. Dalam rangka mengoreksi sikap ilmuwan sosial, kritik yang dikemukakan Syed Hussein Alatas melalui teorinya captive mindmerupakan peta jalan untuk melahirkan ilmu sosial 
yang bersumber dari struktur dan system sosial masyarakat. SH Alatas menyebut bahwa ilmu sosial secara umum di Dunia Ketiga merupakan ilmu sosial yang menjadi korban orientalisme dan Eurosentrisme yang dicirikan oleh cara berpikir yang didominasi pemikiran Barat dengan cara meniru dan bersikap tak kritis. Peniruan tidak kritis tersebut merasuk ke semua tingkatan aktivitas ilmiah, mempengaruhi latar masalah, analisis, abstraksi, generalisasi, konseptualisasi, deskripsi, eksplanasi dan interpretasi (Syed Husen Alatas, 1995; 11-12).

\section{Spirit Profetik dan Asketisme Intelektual}

Agen-agen asing bekerja dalam ragam medan dan banyak kepentingan, mulai dari medan politik, medan sosial dan medan ilmu pengetahuan dengan kepentingan yang sangat beragam mengancam pertumbuhan ilmu social yang khas. Kemunculan teori-teori sosial Nusantara ditandai oleh proses sosial politik yang hegemonik,khususnya proses imperialisme akademik yang berlangsung secara massif. Inisiasi tumbuhnya spirit profetik untuk mengemansipasi dan mentransformasi masyarakat telah terbangun dengan baik pada masa pra kemerdekaan, misalnya H.O.S Tjokroaminoto dan Agus Salim melalui Sarekat Islam mengembangkan konsep sosialisme dalam pergerakan mereka, sebagai suatu sikap politik yang memiliki dua sasaran yakni pertama ke pemerintah kolonial dan kedua kepada masyarakat dengan target transformasi dan emansipasi kesadaran sosialnya.

Spirit profetik tidak hanya mempersoalkan budaya intelektual positivistik yang value free, tetapi juga secara jelas mengharuskan ilmu sosial Indonesia untuk secara sadar memiliki pijakan nilai sebagai tujuannya. Spirit profetik menjadi dasar pijakan pengembangan ilmu sosial atau dalam bahasa Kuntowijoyo dengan istilah Ilmu Sosial Profetik, ilmu yang tidak hanya berhenti pada usaha menjelaskan dan memahami realitas apa adanya tapi lebih dari itu mentransformasikannya menuju cita-cita yang diidamkan masyarakatnya. Ilmu Sosial Profetik kemudian merumuskan tiga nilai penting sebagai pijakan yang sekaligus menjadi unsur-unsur yang akan membentuk karakter paradigmatiknya, yaitu humanisasi, liberasi dan transendensi.

Masyarakat Indonesia merupakan masyarakat yang menghargai nilai-nilai kemanusiaan, nilai-nilai budaya/tradisi sosialnya, artinya manusia yang tidak hanya memusatkan perhatiannya pada manusia sebagaimana dalam antroposentris Barat, tetapi manusia teoantroposentris menjadikan Tuhan sebagai pusatnya, tapi tujuannya adalah untuk kepentingan manusia (kemanusiaan) sendiri. Perkembangan peradaban manusia tidak lagi diukur dengan rasionalitas 
tapi transendensi. Humanisasi diperlukan karena masyarakat sedang berada dalam tiga keadaan akut yaitu dehumanisasi (obyektivasi teknologis, ekonomis, budaya dan negara), agresivitas (agresivitas kolektif dan kriminalitas) dan loneliness (privatisasi, individuasi) (Kuntowijoyo, 2001: 366-369).

Dimensi liberasi Kuntowijoyo menggariskan empat sasaran liberasi, yaitu sistem pengetahuan, sistem sosial, sistem ekonomi dan sistem politik yang membelenggu manusia sehingga tidak dapat mengaktualisasikan dirinya sebagai makhluk yang merdeka dan mulia. Transendensi hendak menjadikan nilai-nilai transendental (keimanan) sebagai bagian penting dari proses membangun peradaban. Transendensi menempatkan agama pada kedudukan yang sangat sentral dalam Ilmu Sosial Profetik. Transendensi adalah dasar dari humanisasi dan liberasi.

\section{Kesimpulan}

Dengan dasar itu,pendidikan sejatinya merupakan bagian yang sangat penting dari kewarnegaraan sipil karena integrasi sosial budaya dapat tercapai melalui pendidikan. Pemerintah melalui Kemendikbud tidak dapat mentransformasi sistem pendidikan yang ideal tanpa tersedianya nilai-nilai tradisional atau nilai-nilai budaya masyarakat, dengan meminjam sosiolog Emile Durkheim, pendidikan dapat menghubungkan Negara lebih dekat kepada individu dan masyarakatnya.

\section{Referensi}

Heru Nugroho, Negara, Universitas dan Banalitas Intelektual: Sebuah Refleksi Kritis dari Dalam, Pidato Pengukuhan Guru Besar Sosiologi Fisipol UGM Yogyakarta, 2012.

Syed Farid Alatas, Alternative Discourses in Asian Social Sciences: Responses to Eurocentrism (India: Sage Publications India, 2006), terjemahan Diskursus Alternatif dalam Ilmu Sosial Asia: Tanggapan Terhadap Eurosentrisme (Bandung: Mizan, 2010).

Ignas Kleden, Sikap Ilmiah dan Kritik Kebudayaan (Jakarta: LP3ES, 1988).

George J. Aditjondro, "Implikasi Pergeseran Ilmuwan Sosial dari "Pro-Negara" ke "ProMasyarakat", dalam Nico Schulte Nordholt dan Leontine Visser (ed.), Ilmu Sosial di Asia Tenggara: dari Partikulraisme ke Universalisme (Jakarta: LP3ES, 1997), hlm. 41-50 
Taufik Abdullah, "Pelaksanaan Masa Lampau dan Arah Masa Depan”, dalam Nico Schulte Nordholt dan Leontine Visser (ed.), Ilmu Sosial di Asia Tenggara, hlm. 57-58

Soedjatmoko, "Etik dalam Perumusan Strategi Penelitian Ilmu-Ilmu Sosial”, dalam A.E. Priyono dan Asmar Oemar Saleh (ed.), Krisis Ilmu-Ilmu Sosial dalam Pembangunan Dunia Ketiga (Yogyakarta: PLP2M), hlm. 115-116; bdk

Gumilar Rusliwa Soemantri, "Membebaskan Ilmu Sosial dari Keterperangkapan Ganda:, dalam Jurnal Ilmu Sosial dan Ilmu Politik, Vol. 9, No. 2, November 2005, hlm. 159-178

Syed Husen Alatas, "The Captive Mind in Development Studies", dalam International Social Science Journal, No. 34 (1), hlm. 11-12

Kuntowijoyo, Muslim Tanpa Masjid(Bandung: Mizan, 2001), hlm. 366-369. 